\title{
Is ultrasound in pregnancy perhaps dangerous after all? A never-ending discussion for over $\mathbf{4 0}$ years!
}

\author{
Ist Ultraschall in der Schwangerschaft doch gefährlich? \\ Eine nicht endende Diskussion seit über 40 Jahren!
}

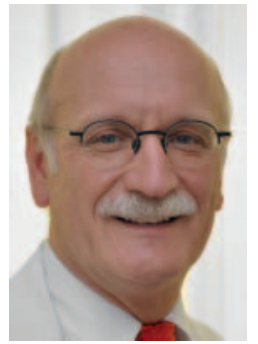

E. Merz

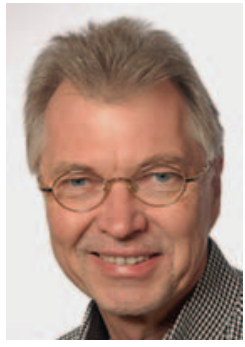

H. Dudwiesus
Correspondence

Prof. Dr. Eberhard Merz

Centre for Ultrasound and Prenatal Medicine, Ebersheimstr. 5, 60320 Frankfurt/Main, Germany

Tel.: ++49/69/768065 59

Fax: $++49 / 69 / 76806631$

merz.eberhard@web.de

Bibliography

Ultraschall in Med 2020; 41: 471-474

Published online: 2020

DOI 10.1055/a-1222-2909

ISSN $0172-4614$

(C) 2020. Thieme. All rights reserved.

Georg Thieme Verlag KG, Rüdigerstraße 14

70469 Stuttgart, Germany
Based on the original underestimation of the damaging effects of $\mathrm{X}$-ray beams, many physicians were initially skeptical of ultrasound. Because of such concerns, the question as to whether and to what extent high-frequency ultrasonic oscillations can be considered truly free of side effects began being intensively examined as early as the $1970 \mathrm{~s}$.

The number of studies and publications on this topic, particularly epidemiological statistics and experimental studies, has since become so vast that the European Federation of Societies for Ultrasound in Medicine and Biology (EFSUMB) set up a permanent committee for reviewing and evaluating all of these studies years ago. This "European Committee for Medical Ultrasound Safety" (ECMUS) produces an annual publication of the results of these reviews in the form of statements and recommendations regarding limit values, mode-specific sound emissions, and safe examination techniques [1]. Similar evaluations and statements have also been published by the American Institute for Ultrasound in Medicine, the British Medical Ultrasound Society, the Society of Obstetricians and Gynaecologists of Canada and the ISUOG [2-5].

Based on the currently valid ECMUS statements and after more than 40 years of searching for ultrasound-induced bioeffects, it can be stated that today's ultrasound methods do not have any side effects for embryos and fetuses when applied properly. There is theoretically the possibility of undesired effects like cavitation or an increase in temperature only in the case of incorrect use, i. e., in the case of excessively long use of high intensities and/or a high sound pressure, excessively long application of Doppler ultrasound, use of contrast agents, or in the case of "a pregnant woman with a high fever". Particularly in the case of pulsed Doppler ultrasound, the ALARA principle (As Low As Reasonably Achievable) should be taken into consideration to prevent a thermal effect by keeping the local exposure as low as possible [6]. Less than 5 seconds per vessel is usually sufficient to achieve a good result.

Since incorrect application of ultrasound can be ruled out with today's ultrasound devices if the examiner has received the corresponding medical training, diagnostic ultrasound in pregnancy can be classified as safe from a scientific and clinical standpoint. Therefore, conventional B-mode ultrasound in particular is considered safe, even in the case of long and repeated exposure, provided that the application-specific limit values are observed. Laboratory experiments on isolated human cells, numerous epidemiological studies as well as long-term observations of children who received prenatal ultrasound have never been able to show any definitive pathological abnormalities so that this mode can be used without hesitation for screening and routine checks. This level of safety applies to 2D ultrasound as well as 3D ultrasound, which is inherently associated with particularly low emission values. Moreover, in the case of 3D ultrasound, the majority of the diagnostic process is performed using stored data [7]. During this process, the patient does not come in contact with the ultrasound transducer and does not even have to be present.

Therefore, it is particularly astonishing that legislators under the auspices of the Federal Ministry for the Environment, Nature Conservation and Nuclear Safety issued a regulatory package at the end of 2018 in the form of the "Ordinance on Protection Against the Harmful Effects of Non-Ionizing Radiation in Human Applica- 
tions" [8], which regulates and significantly limits the use of lasers, high-energy light sources, strong magnetic fields as well as the use of low-dose ultrasound in humans. According to the Federal Ministry for the Environment, Nature Conservation and Nuclear Safety, the regulations are due in particular to the increase in uncontrolled cosmetic applications of the sometimes high-energy fields, e. g. for laser tattoo removal or for ultrasound fat reduction.

Fetal ultrasound exposure for non-medical purposes ("baby TV") is also generally prohibited according to $\S 10$. This ban is certainly justified in the case of ultrasound performed by non-medical personnel for non-medical purposes [9-11]. However, the fact that these regulations practically ban "non-medical" photos of a fetus taken during or after a medical examination as a keepsake for the parents seems to overshoot the mark.

The Federal Ministry for the Environment, Nature Conservation and Nuclear Safety uses not scientifically proven or even disproven speculation to justify the ban and in the draft bill [12] explicitly cites the theories of "Greenbirth e. V.", a non-profit association that is critical or even dismissive of modern obstetrics and prenatal diagnosis. There is no proof for the statements regarding the risk of ultrasound-induced developmental disorders published by this association and the repeatedly stated theory regarding a relationship between early ultrasound and autism was able to be recently disproven in a number of American studies.

If there were such risks, the medical use of ultrasound, particularly in the three screening examinations defined in the Maternity Care Guidelines, would have to be reconsidered in a risk/benefit analysis. However, this is not the case. Quite the contrary! The Federal Ministry for the Environment, Nature Conservation and Nuclear Safety is in agreement with professional societies like the DEGUM and recommends screening examinations for the early diagnosis of any malformations and growth retardation.

Thus, the reason for the ban is not clear, especially since the 3 D/4 D ultrasound examination used for "baby TV" has the lowest sound emission compared to other modes and is associated with the lowest thermal load when performed by a qualified examiner.

In spite of the lack of risks of ultrasound when applied properly, it is important - as already discussed in the editorial of the 2/2020 issue of the European Journal of Ultrasound [13] - for every person performing medical ultrasound examinations in pregnancy to know the safety aspects of ultrasound in prenatal diagnosis. Therefore, we wrote a two-part CME article providing a comprehensive overview of ultrasound safety in pregnancy. Part 1, which is published in this issue, addresses ultrasound-induced bioeffects and part 2, which is scheduled to be published next year, will provide an overview of well-founded scientific studies and their results as well as a critical examination of pseudoscientific claims.

\section{Ist Ultraschall in der Schwangerschaft doch gefährlich? Eine nicht endende Diskussion seit über 40 Jahren!}

Geprägt von den Erkenntnissen über die ursprünglich unterschätzten schädlichen Wirkungen von Röntgenstrahlen, standen viele Mediziner dem Ultraschall anfänglich misstrauisch gegen- über. Aus dieser Besorgnis heraus war bereits in den 70er-Jahren intensiv der Frage nachgegangen worden, ob und inwieweit hochfrequente Ultraschallschwingungen als wirklich frei von Nebenwirkungen postuliert werden durften.

Die Studien und Publikationen zu diesem Themenkreis, insbesondere epidemiologische Statistiken und experimentelle Arbeiten, haben zwischenzeitlich einen fast unüberblickbaren Umfang angenommen, sodass die Europäische Ultraschallgesellschaft, die EFSUMB, bereits vor vielen Jahren eine ständige Kommission zur Sichtung und Bewertung all dieser Studien eingesetzt hat. Dieses „European Committee for Medical Ultrasound Safety (ECMUS)“ veröffentlicht in jährlichem Rhythmus das Ergebnis dieser Reviews in Form von Statements sowie Empfehlungen zu Grenzwerten, zu den Modus-spezifischen Schallemissionen und zu sicheren Untersuchungstechniken [1]. Ähnliche Bewertungen und Statements wurden auch vom American Institute for Ultrasound in Medicine, von der British Medical Ultrasound Society, der Society of Obstetricians and Gynaecologists of Canada und der ISUOG veröffentlicht [2-5].

Auf Basis des gegenwärtig geltenden ECMUS-Statements und nach nunmehr über 40-jähriger Suche nach ultraschallinduzierten Bioeffekten darf festgestellt werden, dass die heutigen Ultraschallverfahren unter sachgerechter Anwendung keine Nebenwirkungen beim Embryo und Fötus haben. Lediglich bei unsachgemäßem Gebrauch, d. h. bei zu langem Einsatz von hohen Intensitäten und/oder hohem Schalldruck, bei übermäßig langem Einsatz der gepulsten Dopplersonografie, beim Einsatz von Kontrastmitteln oder bei „hohem Fieber der Schwangeren“, besteht theoretisch die Möglichkeit unerwünschter Effekte wie Kavitation oder Wärmeentwicklung. Insbesondere bei der gepulsten Dopplersonografie sollte das ALARAPrinzip (As Low As Reasonably Achievable) Berücksichtigung finden, um durch eine so gering wie mögliche lokale Exposition einen thermischen Effekt zu verhindern [6]. Meist reichen hier weniger als 5 Sekunden pro Gefäß, um ein gutes Ergebnis zu erlangen.

Da bei entsprechender medizinischer Ausbildung des Untersuchers mit den heutigen Ultraschallgeräten eine unsachgemäße Anwendung der Sonografie ausgeschlossen werden kann, ist aus wissenschaftlicher und klinischer Sicht der diagnostische Ultraschall in der Schwangerschaft als unbedenkliche Methode einzustufen. So gilt insbesondere die konventionelle B-Mode-Sonografie bei Einhaltung der anwendungsspezifischen Grenzwerte selbst unter langanhaltender und wiederholter Exposition als sicher. Weder die Laborversuche an isolierten menschlichen Zellen, noch die Vielzahl an epidemiologischen Studien wie auch die Langzeitbeobachtungen von pränatal geschallten Kindern haben jemals irgendwelche eindeutigen pathologischen Auffälligkeiten gezeigt, sodass dieser Modus bedenkenlos zum Zwecke des Screenings oder im Rahmen von Routinekontrollen eingesetzt werden kann. Diese Unbedenklichkeit betrifft sowohl die 2-dimensionale Abtastung als auch - anders als oft dargestellt - die 3D-Sonografie, die verfahrensimmanent mit besonders geringen Emissionswerten einhergeht. Dazu kommt, dass bei der 3D-Sonografie der Großteil der Diagnostik an gespeicherten Volumina durchgeführt wird [7]. Dabei hat die Patientin weder Kontakt mit der Ultraschallsonde noch muss sie gar dabei noch anwesend sein.

Umso mehr erstaunt es, dass der Gesetzgeber unter Federführung des Bundesministeriums für Umwelt, Naturschutz und nukleare Sicherheit (BMU) Ende 2018 mit der „Verordnung zum 
Schutz vor schädlicher Wirkung nichtionisierender Strahlung bei der Anwendung am Menschen“ (NiSV)“ [8] ein Vorschriftenpaket erlassen hat, das neben Lasern, hochenergetischen Lichtquellen und starken Magnetfeldern auch den Einsatz von niedrigdosiertem Ultraschall am Menschen reglementiert und signifikant einschränkt. Hintergrund des Regelwerks war nach Verlautbarung des BMU insbesondere die zunehmend unkontrollierte Verbreitung von kosmetischen Anwendungen der teils hochenergetischen Felder, z. B. zur lasergestützten Tattoo-Entfernung oder zur Fettgewebereduktion mittels Ultraschalls.

Auch die Ultraschallexposition des Fötus zu nichtmedizinischen Zwecken (sog. „Babyfernsehen“) wird gemäß § 10 der Verordnung generell untersagt. Dieses Verbot hat sicherlich seine Berechtigung, wenn die Ultraschalluntersuchung von nichtmedizinischem Personal als nichtmedizinische Untersuchung durchgeführt wird [9-11]. Dass man damit praktisch aber auch ein während oder nach einer medizinischen Untersuchung zusätzlich aufgenommenes „nichtmedizinisches“ Foto des Fötus als Erinnerungsfoto für die Eltern damit quasi verbietet, dürfte aber über das Ziel hinausschießen.

In der Begründung des Verbots stützt sich das BMU auch auf wissenschaftlich nicht belegte oder gar zwischenzeitlich widerlegte Mutmaßungen und nennt in diesem Zusammenhang im Referentenentwurf [12] explizit die Thesen von „Greenbirth e. V.“, einem Verein, der der modernen Geburtshilfe sowie der pränatalen Diagnostik kritisch bis ablehnend gegenübersteht. Für die von diesem Verein veröffentlichten Aussagen über das Risiko ultraschallinduzierter Entwicklungsstörungen gibt es keinerlei Belege und auch die wiederholt vorgetragene Vermutung eines Zusammenhangs zwischen Frühultraschall und Autismus konnte jüngst in mehreren amerikanischen Studien widerlegt werden.

Gäbe es derartige Risiken, müsste auch der medizinische Einsatz des Ultraschalls, insbesondere bei den in den Mutterschaftsrichtlinien verankerten 3 Screening-Untersuchungen, im Sinne einer Nutzen-/Risikoanalyse überdacht werden. Dies ist aber nicht der Fall. Im Gegenteil! Das BMU schließt sich den Fachgesellschaften wie der „DEGUM“ an und empfiehlt die Vorsorgeuntersuchungen zur frühzeitigen Diagnostik eventueller Fehlbildungen und Mangelentwicklungen.

Somit ist die Begründung für das Verbot nicht schlüssig, zumal ausgerechnet die für das „Babyfernsehen“ verwendete 3D/4DUltraschalluntersuchung im Vergleich zu anderen Modi mit der geringsten Schallemission und der geringsten thermischen Belastung einhergeht, wenn sie von einem qualifizierten Untersucher durchgeführt wird.

Trotz aller Unbedenklichkeit ist es - wie bereits im Editorial von Heft 2/2020 von Ultraschall in der Medizin aufgeführt [13] - wichtig, dass jeder, der medizinische Ultraschalluntersuchungen in der Schwangerschaft durchführt, die Sicherheitsaspekte des Ultraschalls in der pränatalen Diagnostik kennt. Aus diesem Grund haben wir einen CME-Artikel in 2 Teilen vorbereitet, der einen umfassenden Überblick über das Gebiet der sonografischen Sicherheit in der Schwangerschaft vermittelt. Teil 1, der diesem Heft zugeordnet ist, befasst sich mit den ultraschallinduzierten Bioeffekten; Teil 2, dessen Publikation für das nächste Jahr geplant ist, wird einen Überblick über fundierte wissenschaftliche Studien und deren Ergebnisse geben und pseudowissenschaftliche Behauptungen kritisch hinterfragen. 


\section{Conflict of Interest}

The authors declare that they have no conflict of interest.

\section{References}

[1] Kollmann C, Jenderka KV, Moran CM et al. EFSUMB Clinical Safety Statement for Diagnostic Ultrasound - (2019 revision). Ultraschall in der Medizin (Stuttgart, Germany: 1980) 2019. doi:10.1055/a-1010-6018

[2] Safety Group of the British Medical Ultrasound Society. Guidelines for the safe use of diagnostic ultrasound equipment. https://www.bmus.org/sta tic/uploads/resources/BMUS-Safety-Guidelines-2009-revisionFINAL-Nov-2009.pdf

[3] AIUM-ACR-ACOG-SMFM-SRU Practice Parameter for the Performance of Standard Diagnostic Obstetric Ultrasound Examinations. J Ultrasound Med 2018; 37: E13-E24 https://www.aium.org/resources/guidelines/ obstetric.pdf

[4] Bly S, Van den Hof MC. Diagnostic Imaging Committee, Society of Obstetricians and Gynaecologists of Canada. Obstetric ultrasound biological effects and safety. J Obstet Gynaecol Can 2005; 27: 572-580

[5] Salvesen K, Lees C, Abramowicz J et al. Board of International Society of Ultrasound in Obstetrics and Gynecology (ISUOG). ISUOG statement on the safe use of Doppler in the 11 to $13+6$-week fetal ultrasound examination. Ultrasound Obstet Gynecol 2011; 37: 628
[6] Rott HD. Ultraschalldiagnostik: Neuere Bewertung der biologischen Sicherheit. Dt Ärztebl 1996; 93: A-1533-1537 (Heft 23)

[7] Merz E, Pashaj S. Advantages of 3D ultrasound in the assessment of fetal abnormalities. J Perinat Med 2017; 45: 643-650

[8] Bundesgesetzblatt Jahrgang 2018 Teil I Nr. 41, ausgegeben zu Bonn am 5. Dezember 2018.

[9] Merz E. 3D/4D-Ultrasound in Obstetrics - Baby TV without Diagnostics? Ultraschall in Med 2008; 29: 156-158

[10] Abramowicz JS. Nonmedical use of ultrasound: bioeffects and safety risk. Ultrasound Med Biol 2010; 36: 1213-1220

[11] Bioeffects and Safety Committee, Salvesen K, Lees $C$ et al. Board of the International Society of Ultrasound in Obstetrics and Gynecology (ISUOG). ISUOG-WFUMB statement on the non-medical use of ultrasound, 2011. Ultrasound Obstet Gynecol 2011; 38: 608

[12] Referentenentwurf des Bundesministeriums für Umwelt, Naturschutz und nukleare Sicherheit. Entwurf einer Verordnung zur weiteren Modernisierung des Strahlenschutzrechts. 2018: S. 439 https://www. bmu.de/gesetz/referentenentwurf-einer-verordnung-zur-weiterenmodernisierung-des-strahlenschutzrechts/

[13] Heling KS, Kozlowski P. Safety aspects of ultrasound in prenatal diagnosis. Ultraschall in Med 2020; 41: 116-119 